\title{
Seasonal Distribution of Nutrients and Primary Productivity on the Eastern Continental Shelf of Venezuela as Influenced by the Orinoco River
}

\author{
Jaime Bonilla, ${ }^{1}$ William Senior, ${ }^{1}$ John Bugden, ${ }^{2}$ \\ OLIVER ZAFIRIOU, ${ }^{3}$ AND RONALD JONES ${ }^{2}$
}

\begin{abstract}
Nitrogenous nutrients, dissolved silicate, and salinity were measured in surface waters and shallow hydrocasts along similar cruise tracks during the spring (dry season) and fall (wet season) of 1988 . Both cruises transected the eastern Caribbean, transited the Gulf of Paria, ran parallel to the Orinoco Delta and into the main channel of the Orinoco River. Trends in primary productivity were also measured by daily carbon 14 incubations. In both seasons, samples covered the range from highly oligotrophic and transparent to highly productive and rich in biogenic and abiogenic particulate matter. Most of the Orinoco outflow appears to turn $\mathbf{N}$ to $\mathrm{NW}$ and remains in shallow waters off Venezuela and surrounding Trinidad, permitting benthic regeneration of river-borne nutrients. However, the role of the Orinoco and associated low-salinity coastal waters in fertilizing large areas of the eastern Caribbean basin, as suggested by satellite imagery, can be approximated crudely from the nutrient composition at Boca de Dragon, which is representative of the nutrient status of these waters as they flow into deeper Caribbean waters. Additional nutrients may be supplied to the area primarily from Amazon-derived water entering the Caribbean Basin further north, with some coastal upwelling along the continental shelf in the dry season.
\end{abstract}

\section{INTRODUCTION}

Coastal oceanic water masses, especially those located in the tropics, are among the most fertile and productive. This biological and organic richness may result from high loads of nitrogen, phosphorus and silicon supplied by hydrodynamic processes resulting from continental drainage, or from coastal upwelling processes during seasons of winds favoring this process. Within the context of coastal bioecosystems, estuarine-deltaic zones are notable as transition environments between the ocean and the continent. The Orinoco River system in Venezuela provides one of the largest-scale examples of these interactions. It has a major influence on the hydrographic and biological conditions of the estuarine system of the Gulf of Paria and the Caribbean Sea.

The Orinoco River begins near Brazil, at the junction of Sierra Párima and Sierra Unturan, and flows over an area of $2560 \mathrm{~km}^{2}$, of which $1670 \mathrm{~km}^{2}$ are navigable. It irrigates a flood plain of $981,000 \mathrm{~km}^{2}$ in Venezuela, Colombia, and Brazil, is the only South American river with a true delta, and has an ocean front of $300 \mathrm{~km}$. Its principal affluent is the Caroni River, with a brown-ochre color, which is mixed with the waters of the Orinoco, which are yellow. The Orinoco flow is turbulent and contains a large amount of suspended clay. These Orinoco-Caroni waters are rich in organic and inorganic matter which is transported to the Atlantic Ocean and the Caribbean Sea through the estuarine-deltaic system. The Orinoco River contributes a large amount of suspended sediments $\left(86.3 \times 10^{6}\right.$ tons $\left.\mathrm{yr}^{-1}\right)$, with an average water flow

\footnotetext{
${ }^{1}$ Instituto Oceanográfico de Venezuela, Universidad de Oriente, Cumaná.

${ }^{2}$ Department of Biological Sciences and Drinking Water Research Center, Florida International University, Miami.

${ }^{3}$ Woods Hole Oceanographic Institution, Woods Hole, Massachusetts.
}

Copyright 1993 by the American Geophysical Union.

Paper number $92 \mathrm{JC} 02761$.

0148-0227/93/92JC-02761\$05.00 of $33.95 \times 10^{3} \mathrm{~m}^{3} \mathrm{~s}^{-1}$ [Salazar, 1989], second only to that of the Amazon. The flow regime is characterized by precipitation throughout the year, with maximum flow in August and minimum flow in March.

The estuaries formed in the delta are known as Boca Ajies and Boca Bagre in the Gulf of Paria, and Boca Grande or Boca de Navios, where the navigation channel is located (Figure 1). Knowledge of the estuarine-deltaic system of the Orinoco and the Gulf of Paria dates from 1954, when Van Andel and Postma described the hydrographic, climatological and sedimentary conditions of the area [Morelock, 1972; Eisma et al., 1978]. The formation of muddy plains in the deltaic coast is due to deposition of sediments transported to the northwest by the Guyana current. Butenko et al. [1981] reported the formation of a clay wedge in the delta area up to about $80 \mathrm{~km}$ into the adjoining Atlantic, with additional organic clays and inorganic input from the Amazon River. This was confirmed by Milliman et al. [1982], who found montmorillonite characteristic of the clay sediments of the Amazon River in the Orinoco delta, also transported by the Guyana current. Herrera and Masciangioli [1984] determined that the predominant circulation in the coastal area of the delta consists of surface currents generated by the trade winds moving to the west and northwest. The hydrographic and chemical conditions of the sediments in the Gulf of Paria were studied by Benitez and Okuda [1976], Bonilla [1977], and Bonilla and Lin [1979]. The geochemical characteristics of the sediments in parts of the river and delta were studied by Bonilla et al. [1985]. Müller-Karger and Varela [1988] determined that the nutrient influence of the Orinoco River on the Caribbean Sea reaches Puerto Rico, based on the concentration of pigments during the high flow season for the Orinoco (August-October). Salazar [1989] studied the hydrogeochemical conditions of the estuarine-deltaic region of the Orinoco, from the island of Curiapo inside the river to $180 \mathrm{~km}$ into the Atlantic Ocean.

In these tropical bioecosystems there are two seasons: a dry season from December to April, and a rainy season from 


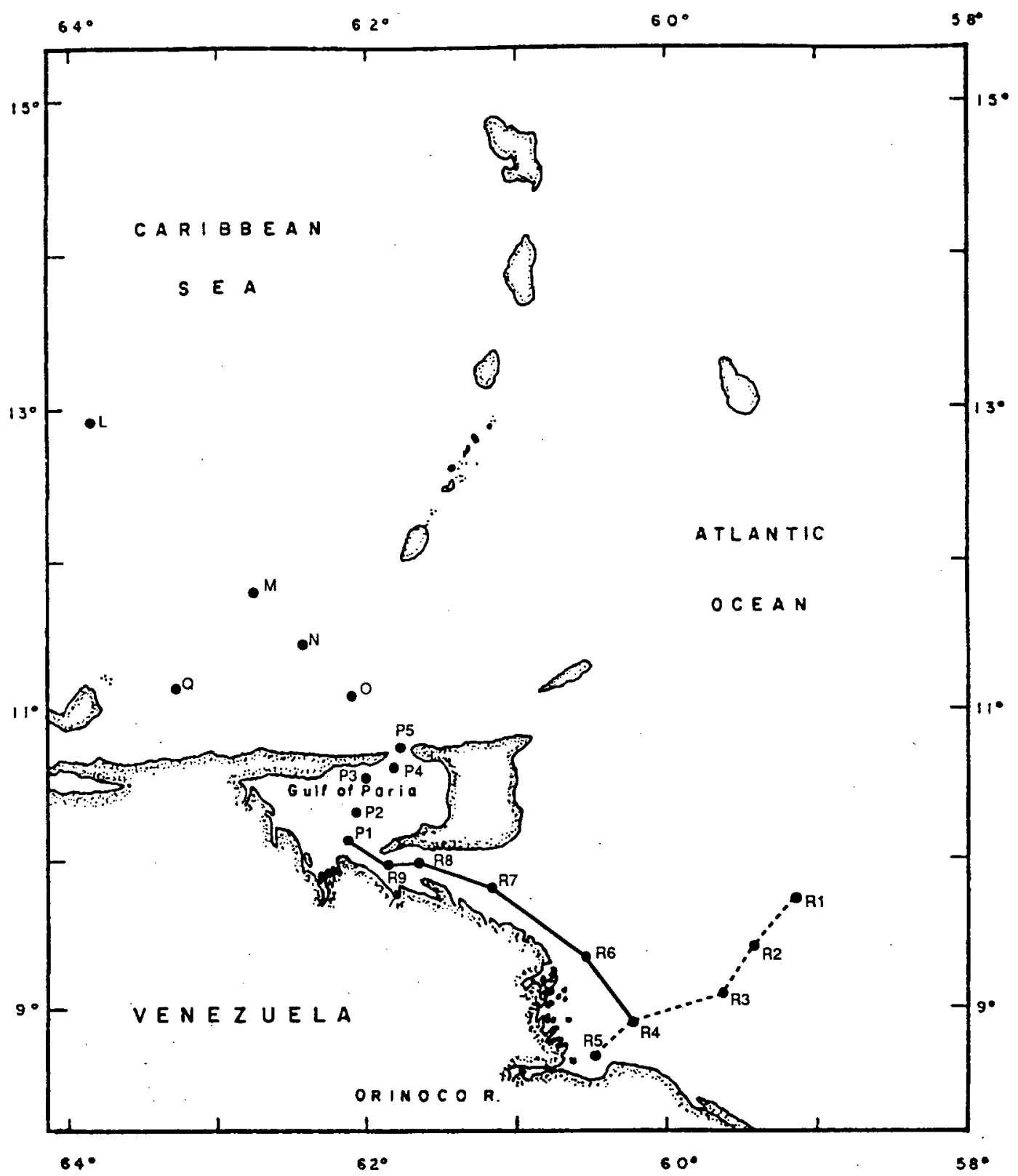

Fig. 1. Location of the sampling sites from Colombus Iselin cruises CI-8805 and CI-8816, spring and fall 1988 (solid line, E-W transect; dashed line, NE-SW transect).

May to November. Evaporation is highest in February (129 $\mathrm{mm})$ and lowest in November $(76 \mathrm{~mm})$, while precipitation is highest in August $(127 \mathrm{~mm})$ and lowest in April $(19 \mathrm{~mm})$. Thus the timing of the two cruises reported here nearly coincided with the two extremes. Westerly winds are prevalent, with an eastern component during most of the year. A semi-diurnal tide regime dominates in the estuarine-deltaic region [Salazar, 1989].

Here we summarize the saline stratification, nutrient distributions, and primary productivity measurements from the spring (April 1988) and fall (September 1988) cruises. We focus on longitudinal transects NE-SW and E-W from the mouth of the Orinoco. This paper focuses on the near-shore data (all data $S$ of $\approx 11^{\circ} \mathrm{N}$ ), as studies in that area were the most intensive and the riverine impact is strongest. For effects in the Caribbean $\mathrm{N}$ of $11^{\circ} \mathrm{N}$, see the accompanying paper [Zika et al., this issue]. In order to better understand the hydrochemical mechanisms of the delta, conservative and nonconservative processes resulting from the runoff of the Orinoco during high and low flow are considered.

\section{METHODS}

\section{Source of Samples}

Water samples were collected in the estuarine-deltaic system of the Orinoco River, Gulf of Paria, and adjacent areas (Figure 1) during research cruises $\mathrm{CI}-8805$ in the spring (April 1988) and fall CI-8816 (September 1988) on board the R/V Columbus Iselin. Seawater samples were taken using a rosette sampler (General Oceanics, Miami, Florida) consisting of twelve 5-L teflon-lined polyvinyl chloride Niskin bottles. The rosette was fitted with a Neil Brown conductivity, temperature, and depth (CTD) probe. Additional surface 
( $2 \mathrm{~m}$ ) samples were collected from the through-the-hull teflon bow pumping system.

\section{Nutrient Analyses}

Water samples were collected in $60-\mathrm{mL}$ Nalgene bottles and refrigerated until analyzed. Samples were analyzed within 24 hours after collection. Turbid samples were filtered using $0.45 \mu \mathrm{m}$ pore-size Acrodisc disposable filter assemblies (Gelman Sciences, Ann Arbor, Michigan).

Nutrient determinations $\left(\mathrm{NO}_{2}^{-}, \mathrm{NO}_{3}^{-}, \mathrm{Si}(\mathrm{OH})_{4}\right.$ ) were performed on an Alpkem RFA-300 nutrient analyzer (Alpkem Corp., Clackamas, Oregon). All nutrient determinations were measured against internal standards according to the RFA methodology handbook (Alpkem).

\section{Primary Productivity Measurements}

Surface water $(\approx 0-2 \mathrm{~m})$ samples were collected in BOD bottles to which $0.95 \mathrm{~mL}$ of $\mathrm{NaH}^{14} \mathrm{CO}_{3}\left(2.5 \mu \mathrm{Ci} \mathrm{mL}{ }^{-1}\right.$, $42.37 \mathrm{nmol} \mathrm{mL} \mathrm{m}^{-1}$, Amersham Corp., Arlington Heights, Illinois) was added. The samples were irradiated in full sunlight in a flowing seawater bath for 3 hours (dark controls were covered with aluminum foil). After irradiation the samples were filtered through $\mathrm{GF} / \mathrm{F}$ glass fiber filters (Whatman International Ltd., Maidstone, England), rinsed with 50 $\mathrm{mL}$ of $1 \mathrm{~N} \mathrm{HCl}$ and stored for further analysis. Integrated photosynthetically active radiation (PAR) was measured with a LI-COR (model 1800) calibrated spectroradiometer. Radioactivity was determined with a Beckman LS 3801 liquid scintillation counter (Beckman Instruments, Fullerton, California). Primary productivity values were calculated as $\mu \mathrm{gC}$ fixed per $\mathrm{m}^{3} \mathrm{~h}^{-1}$.

\section{RESULTS}

\section{Spring and Fall Salinity Distributions}

The spring-fall salinity distributions (Figures 2-5) are dramatically different. In spring there was a sharp freshwater-seawater interface within the navigation channel and upstream of Pt. Barima, so that the NE-SW transect (Figure 2) never encountered pure river water $\left(S_{\min }=8 \mathrm{ppt}\right.$ at R5 at ebb tide). The E-W transect (Figure 4), as close inshore as feasible navigationally, also encountered only relatively saline waters $(S>30 \mathrm{ppt}$ ) because the saltwater-freshwater gradient was centered close inshore in the nonnavigable waters of the Orinoco's extensive deltaic system and distributaries in spring.

In fall, both sections were within the core of the near-field freshwater-saltwater mixing zone (Figures 3, 5). The E-W transect and the Gulf of Paria was roughly $50 \%$ saltwater at that time, while the NE-SW transect encountered $S=0 \mathrm{ppt}$ water from surface to bottom at R5. The surface distribution of salt (not shown) on these two cruises thus resembled that given by Rodriguez [1975] for April, but in September the E-W transect and Gulf of Paria waters were already almost twice as saline as those reported for August, suggesting that the peak flow was already well past and the gradual advection and mixing of this large input with seawater were underway. Where there was sufficient water for navigation by the $\mathrm{R} / \mathrm{V}$ Iselin, the delta region of the Orinoco River exhibited a typical salt wedge circulation which governs hydrographic and chemical conditions in deeper waters. Thus the spring versus fall effects of the riverine inflow are limited primarily to a shallow surface layer and are hardly detectable even at $50 \mathrm{~m}$. This factor can be seen clearly by comparing salt, silica, and nitrate seasonal differences along both transects: NE-SW (Figure 2, spring; Figure 3, fall) and E-W (Figure 4, spring; Figure 5, fall). The tendency to upwelling in the spring and its relaxation in the fall are clearly indicated in the NE-SW (onshore-offshore) sections by the sloping and horizontal (respectively) isolines for $S=$ $36 \mathrm{ppt}$, and silicate or nitrate $1 \mu \mathrm{M}$. The $\mathrm{E}-\mathrm{W}$ transect comparison most clearly shows the much larger extent of freshwater influence: the spring top-bottom contrast is $\approx 31$ $36.5 \mathrm{ppt}$, while in the fall the range is $\approx 13-36.6 \mathrm{ppt}$.

The sloping isolines indicate the dry season upwelling of intermediate water from the southeastern Atlantic in the platform at Boca Grande. Water of salinity $35.5 \mathrm{ppt}$ at $30 \mathrm{~m}$ (R1) ascends to the surface layers $(2-10 \mathrm{~m})$, pushing the freshwater mass into the river (Figure 2) from the surface (R3) with changes in salinity, delineating this area of the estuary from the salt wedge towards the bottom at R5, where the wedge's apex is formed. The mixing zone was between R5 and R6 near the platform at Boca Grande. At a depth of 90 to 140 $\mathrm{m}$ there was a cold, deep-water mass from the southeastern Atlantic which was higher in salinity (36.8-37.15 ppt) between $\mathrm{R} 1$ and $\mathrm{R} 2$, rich in nitrogenous compounds (nitrite, $0.18-0.16$ $\mu \mathrm{M}$; nitrate, $0.47-6.2 \mu \mathrm{M})$ and low in silicate $(0.12-0.35 \mu \mathrm{M})$. Thus, during the dry season, when the Orinoco has its lowest flow, its influence is limited to a narrow fringe stretching along the estuarine-deltaic area (Figures 2 and 3).

\section{Nutrients and Primary Productivity}

The vertical nutrient distributions are also shown in Figures $2-5$, while the surface values and primary productivity data are given in Figures 6 and 7. Table 1 presents a highly condensed summary of the data for both seasons in the vicinity of the Orinoco River.

Given the restrictions imposed in the spring by navigation requirements and the strong tendency of the river water to spread over the salt water in a thin difficult-to-sample sheet in both seasons, these data are obviously too sparse and unrepresentative of the river-delta-coastal system as a whole to permit a detailed characterization of the region in either season, or a detailed interseasonal comparison. The purpose of gathering these data was rather to provide ancillary information for the more detailed process-oriented studies reported in other papers in this Special Section.

Nevertheless, a few issues of general interest to the biogeochemistry of this fascinating but relatively littlestudied region can be addressed with this data set. They are discussed below. Some of these same issues are also addressed from different perspectives in some of the accompanying papers (e.g., the $\mathrm{Si}$ budget and $\mathrm{Ra}$-Si relationships [Moore and Todd, this issue]; primary productivity, nutrients, and specific pigment distributions [Bidigare et al., this issue]).

\section{Discussion}

\section{Silicate and (Nitrate Plus Nitrite) in Spring and Fall}

Coastal nitrogen cycling is intense and complex [Carpenter and Capone, 1983]. The available data provide strong qualitative confirmation of the expected intense biological cycling in this region, as discussed previously [D'Armas, 

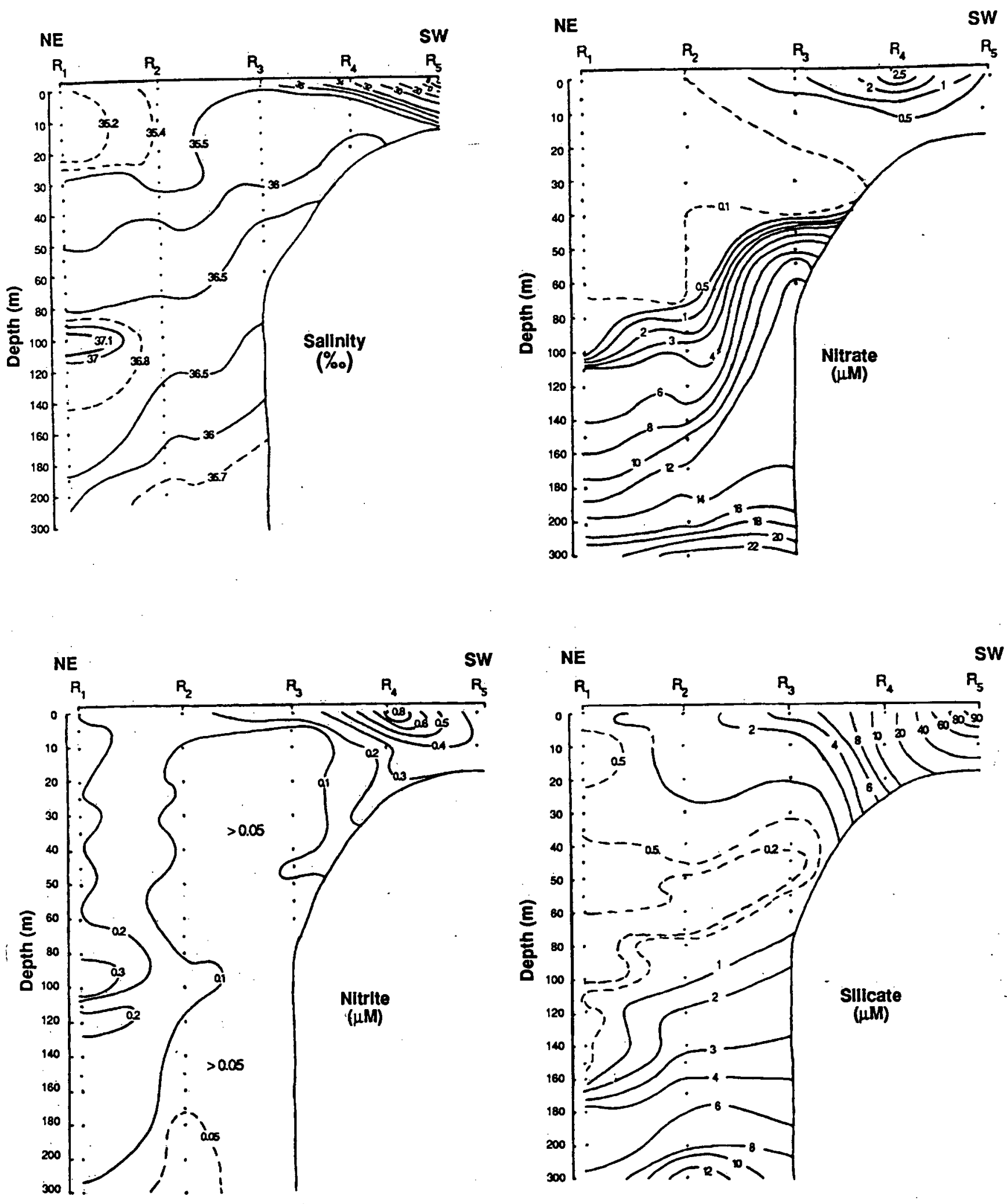

\section{NE-SW Spring}

Fig. 2. Depth profile of salinity, nitrite, nitrate, and silicate on a NE-SW transect, spring 1988. 

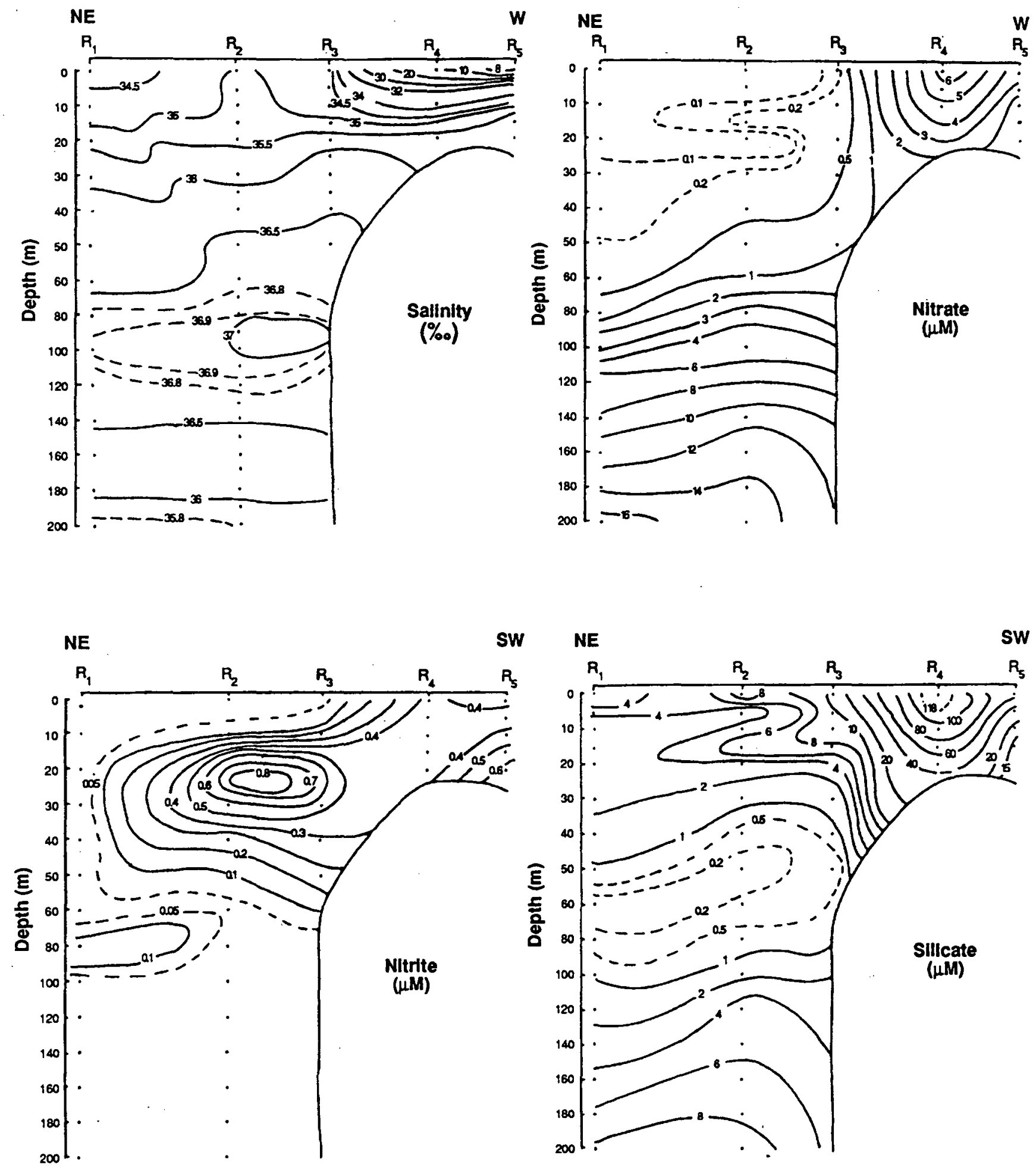

\section{NE-SW Fall}

Fig. 3. Depth profile of salinity, nitrite, nitrate, and silicate on a NE-SW transect, fall 1988.

1986; Salazar, 1989] for November conditions in the water column of the delta region. Sedimentary conditions there have been discussed by Milliman et al. [1982], Eisma et al. [1978], and Kennicut et al. [1987] and conditions in the Gulf of Paria have been described by Bonilla and co-workers, as referenced in the introduction.

In addition to salt, other semiconservative tracers are useful in estuarine studies, most classically dissolved silicate 

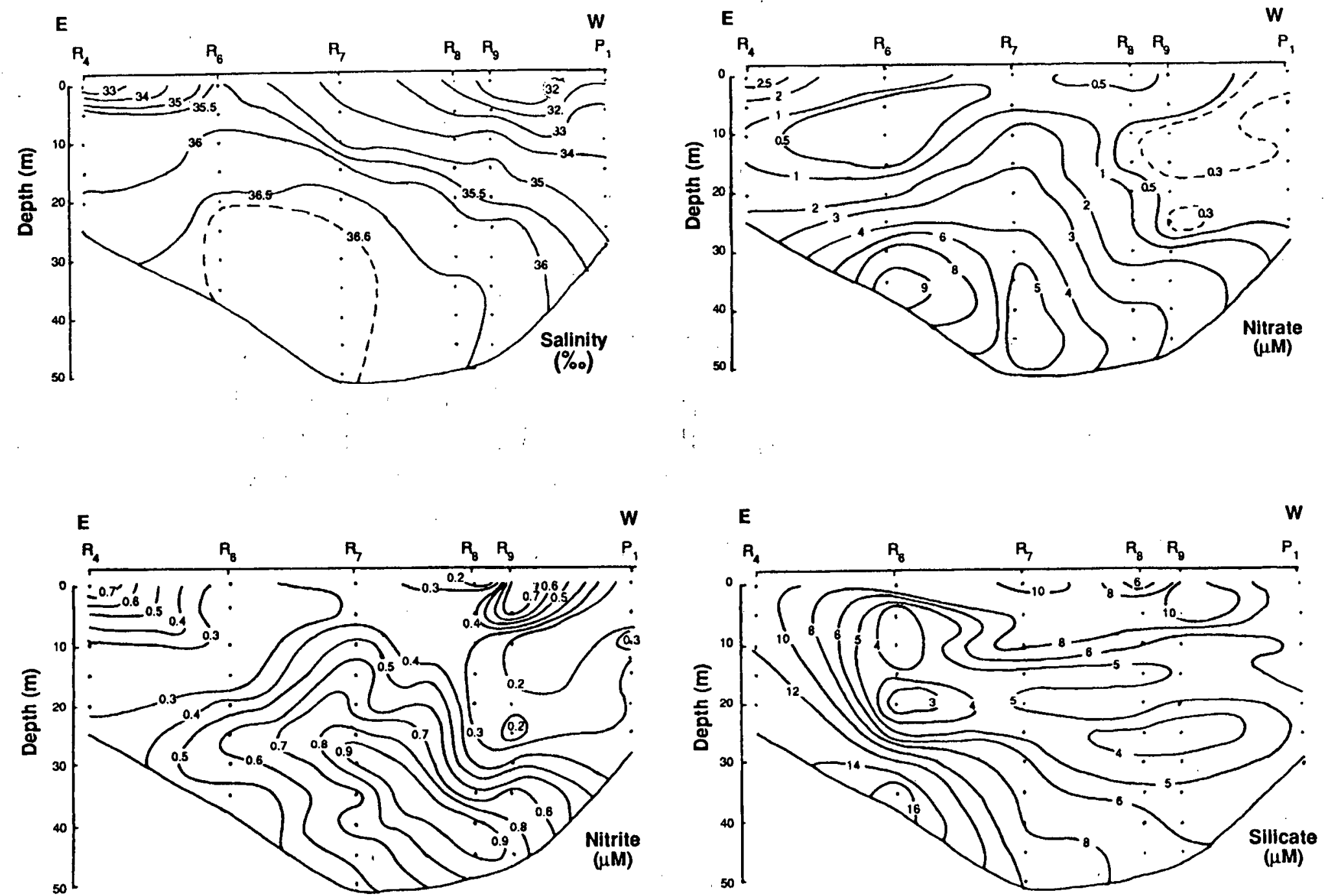

\section{E-W Spring}

Fig. 4. Depth profile of salinity, nitrite, nitrate, and silicate on an E-W transect, spring 1988. 

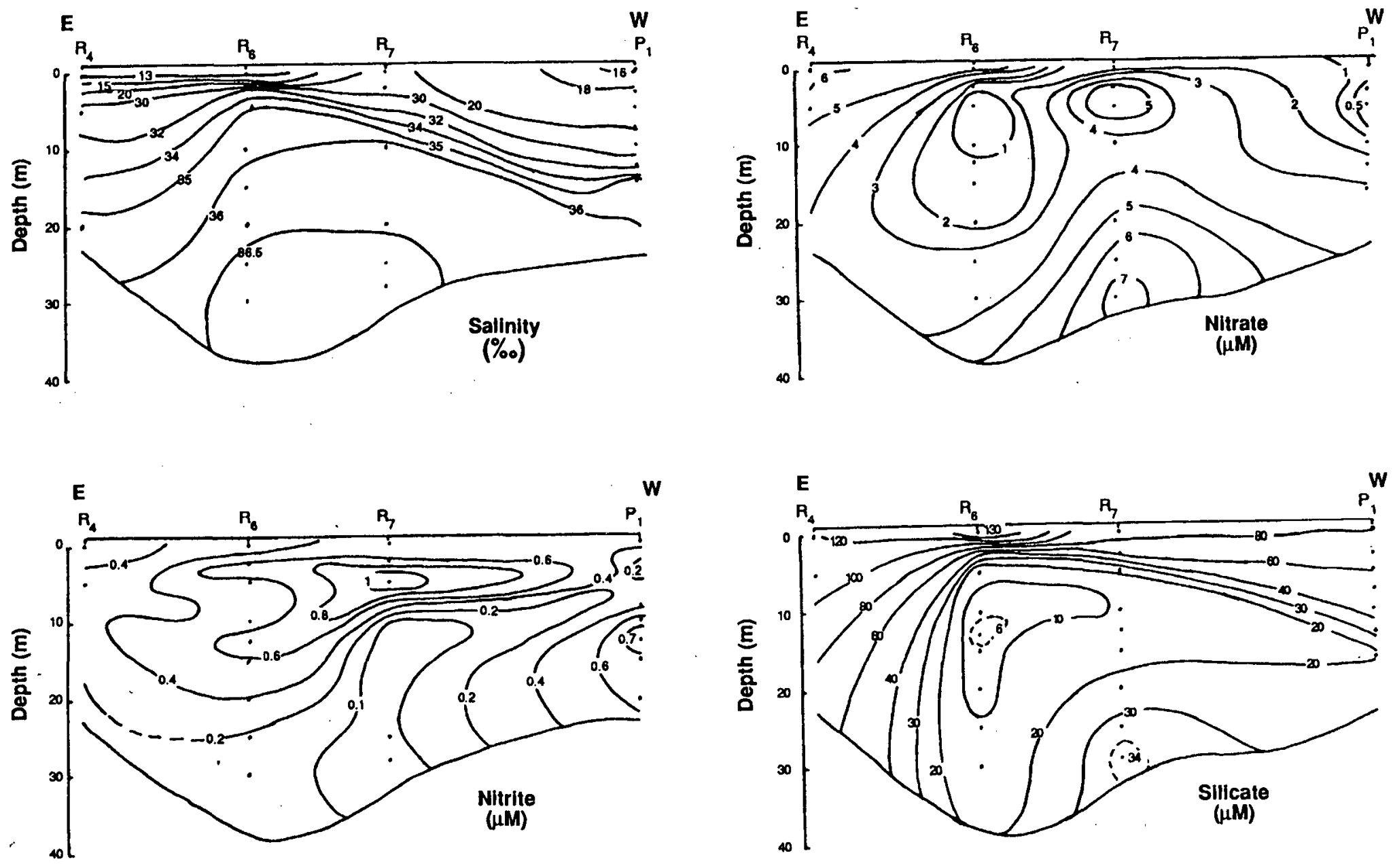

\section{E-W Fall}

Fig. 5. Depth profile of salinity, nitrite, nitrate, and silicate on an E-W transect, fall 1988. 

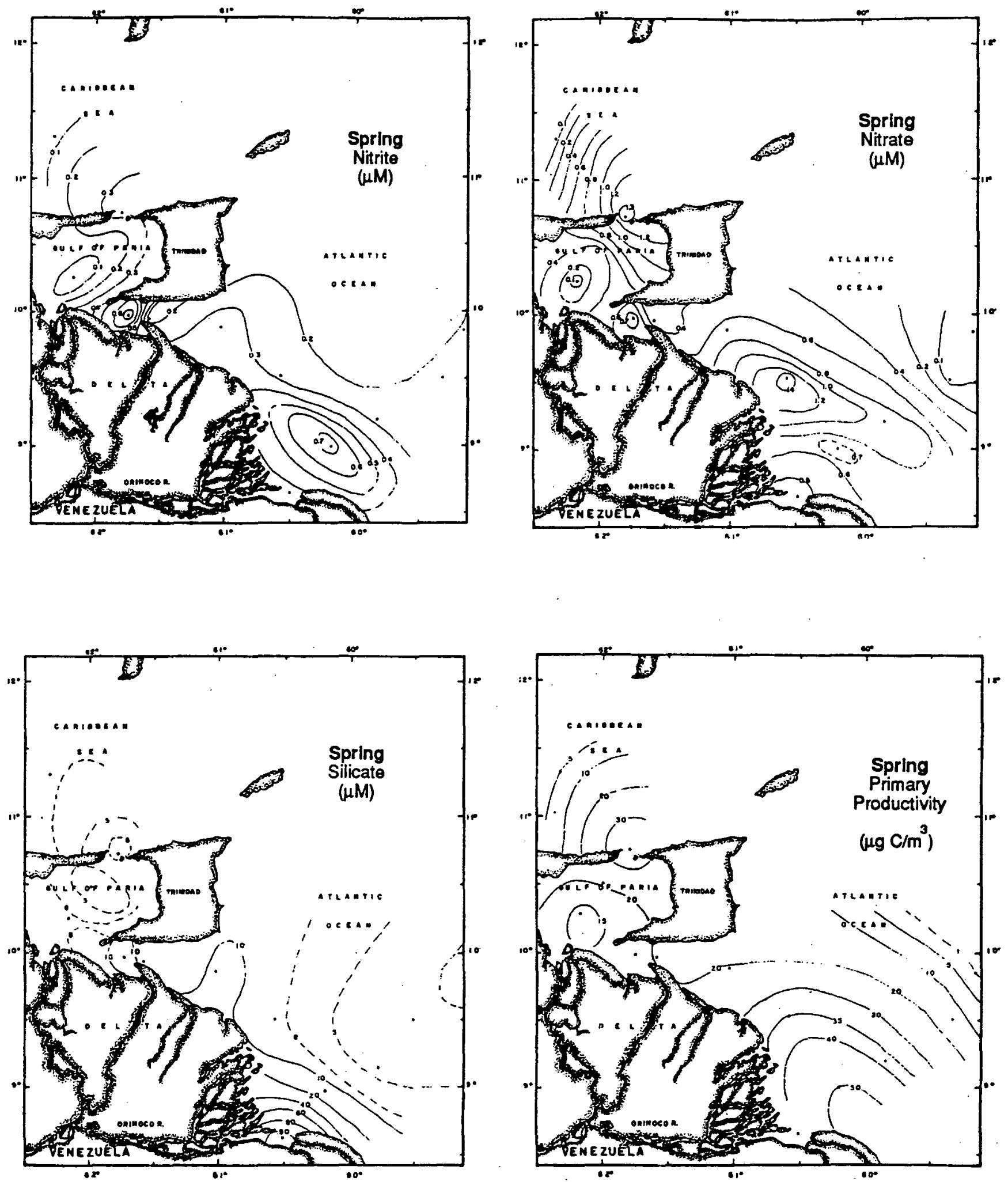

Fig. 6. Spatial distribution of nitrite, nitrate, silicate, and primary productivity in the surface water during the spring 1988. Primary productivity values are expressed as $\mu \mathrm{gC} \mathrm{m} \mathrm{m}^{-3} \mathrm{~h}^{-1}$.

[Burton et al., 1970; Liss, 1976], as exemplified recently for the Mackenzie Shelf Estuary by MacDonald et al. [1989]. However, silicate distributions must be interpreted with care because biological uptake and subsequent sinking and redissolution of biogenic opal in the water and on the bottom can lead to seriously nonconservative behavior on spatial and temporal scales that need to be defined empirically in each system [e.g., Edmond et al., 1981].

However, use of Si as a tracer has a history in the greater eastern Caribbean basin with respect to understanding the 

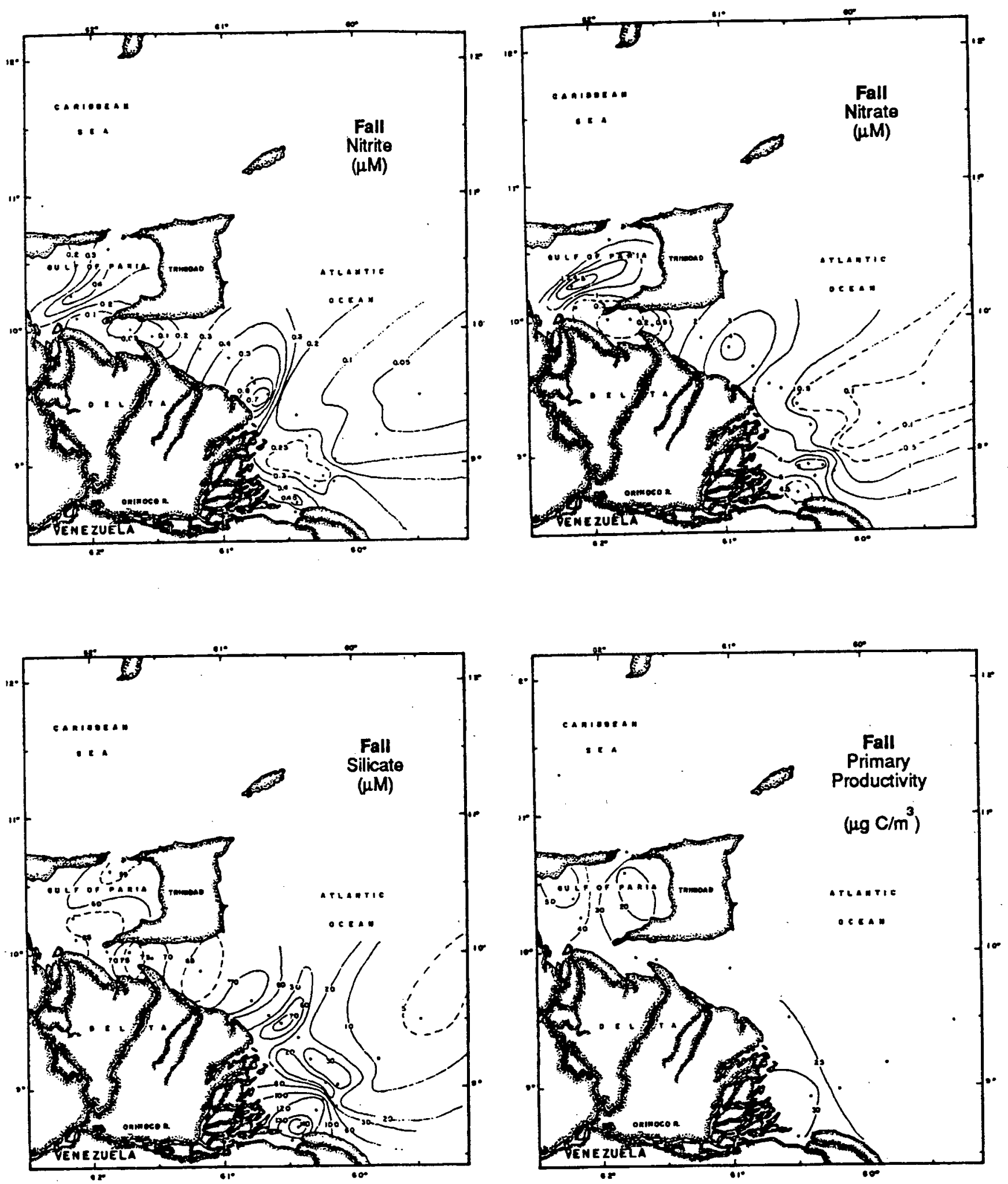

Fig. 7. Spatial distribution of nitrite, nitrate, silicate, and primary productivity in the surface water during the fall 1988. Primary productivity values are expressed as $\mu \mathrm{gC} \mathrm{m}^{-3} \mathrm{~h}^{-1}$.

influence and seasonal variability of the great river systems to the southeast (Amazon and Orinoco) versus rain inputs. Froehlich et al. [1978] first used Si sections to suggest that rivers, not rainfall, were the principal cause of the seasonal surface freshening as far away as Puerto Rico. More re- cently, Moore et al. [1986] used Ra-Si relationships to construct quantitative, sensitive tracers of the remote riverine inputs to this region. The radiochemistry approach was also applied on CI-8805 and 8816; the combined use of Si and radiochemical data to determine the "estuarine end mem- 
TABLE 1. Nutrient Content and Primary Productivity in Different Offshore Regions of Estuarine-Deltaic Systems of the Orinoco

\begin{tabular}{|c|c|c|c|c|c|c|c|}
\hline \multirow[b]{2}{*}{ Region } & \multirow{2}{*}{$\begin{array}{l}\text { Parameter } \\
\text { Measured }\end{array}$} & \multicolumn{3}{|c|}{ Spring } & \multicolumn{3}{|c|}{ Fall } \\
\hline & & Minimum & Maximum & Average & Minimum & Maximum & Average \\
\hline \multirow[t]{4}{*}{ Dragon's Mouth } & $\mathrm{NO}_{2}^{-}$ & 0.27 & 0.56 & 0.45 & - & - & - \\
\hline & $\mathrm{NO}_{3}^{-}$ & 0.55 & 8.12 & 5.34 & - & - & - \\
\hline & $\mathrm{Si}(\mathrm{OH})_{4}$ & 3.21 & 6.42 & 4.76 & - & - & - \\
\hline & PP & 31.0 & 31.0 & $31.0 *$ & 12.9 & 12.9 & $12.9^{*}$ \\
\hline \multirow[t]{4}{*}{ Gulf of Paria } & $\mathrm{NO}_{2}^{-}$ & 0.16 & 0.60 & 0.34 & 0.06 & 1.01 & 0.41 \\
\hline & $\mathrm{NO}_{3}^{-}$ & 0 & 1.00 & 0.41 & 0.26 & 7.03 & 3.25 \\
\hline & $\mathrm{Si}(\mathrm{OH})_{4}$ & 4.90 & 7.43 & 6.33 & 10.53 & 68.64 & 40.75 \\
\hline & PP & 14.0 & 14.0 & $14.0^{*}$ & 26.0 & 52.8 & $38.0 \dagger$ \\
\hline \multirow[t]{4}{*}{ Serpent's Mouth } & $\mathrm{NO}_{2}^{-}$ & 0.12 & 0.92 & 0.42 & - & - & - \\
\hline & $\mathrm{NO}_{3}^{--}$ & 0 & 3.37 & 0.98 & - & - & - \\
\hline & $\mathrm{Si}(\mathrm{OH})_{4}$ & 0.93 & 11.86 & 6.01 & - & - & - \\
\hline & PP & - & - & - & - & - & - \\
\hline \multirow[t]{4}{*}{ Shelf } & $\mathrm{NO}_{2}^{-}$ & 0.20 & 0.97 & 9.55 & 0.15 & 0.71 & 0.46 \\
\hline & $\mathrm{NO}_{3}^{--}$ & 0 & 9.30 & 3.75 & 0 & 3.89 & 1.45 \\
\hline & $\mathrm{Si}(\mathrm{OH})_{4}$ & 2.05 & 17.92 & 6.83 & 4.61 & 28.00 & 9.41 \\
\hline & PP & 35.0 & 35.0 & $35.0^{*}$ & 2.9 & 2.9 & $2.9 *$ \\
\hline \multirow[t]{4}{*}{ River (surface transect DM) } & $\mathrm{NO}_{2}^{-}$ & 0.36 & 2.09 & 1.38 & 0.02 & 1.01 & 0.30 \\
\hline & $\mathrm{NO}_{3}^{-}$ & 0.13 & 4.52 & 3.24 & 0 & 6.55 & 5.00 \\
\hline & $\mathrm{Si}(\mathrm{OH})_{4}$ & 10.84 & 98.26 & 41.46 & 12.20 & 149.80 & 110.46 \\
\hline & PP & 50.0 & 50.0 & $50.0^{*}$ & 21.6 & 31.2 & $26.4 \ddagger$ \\
\hline \multirow[t]{4}{*}{ Ocean } & $\mathrm{NO}_{2}^{-}$ & 0.02 & 0.36 & 0.12 & 0 & 0.86 & 0.08 \\
\hline & $\mathrm{NO}_{3}^{-}$ & 0 & 22.75 & 4.12 & 0 & 16.48 & 3.58 \\
\hline & $\mathrm{Si}(\mathrm{OH})_{4}$ & 0 & 12.00 & 1.50 & 0 & 9.86 & 3.52 \\
\hline & PP & 1.0 & 1.0 & $1.0^{*}$ & - & - & - \\
\hline
\end{tabular}

$\mathrm{PP}$, primary productivity $\left(\mu \mathrm{gC} \mathrm{m} \mathrm{m}^{-3} \mathrm{~h}^{-1}\right), \mathrm{NO}_{2}^{-}, \mathrm{NO}_{3}^{-}$, and $\mathrm{Si}(\mathrm{OH})_{4}(\mu \mathrm{M})$.

*One value only, no average, depth $5 \mathrm{~m}$.

†Average of four values, depth $5 \mathrm{~m}$

$\ddagger$ Average of two values, depth $0 \mathrm{~m}$.

ber" by this approach is discussed in their paper [Moore and Todd, this issue]. Hence it is of interest to examine its behavior also in the estuarine region which may alter this water before it reaches the eastern Caribbean.

Figure 8 shows silicate versus nitrate plus nitrite plots for both seasons along with the mixing lines expected for spring and fall Orinoco river water plus oligotrophic seawater (nutrient-salinity plots cannot be used in spring, when all the low-salinity samples were acquired in rapid succession from the pumping system and could not be accurately matched with salinities). In spring (solid symbols) the data are from the vicinity of R4-R5, whereas in fall the same [Si] range was covered over much of the E-W transect outside of the Gulf of Paria. As noted above, the highest Si values in both seasons closely approximate those expected from the riverine data of Lewis and Saunders [1989]. In contrast, in both seasons $\mathrm{NO}_{2}^{-}+\mathrm{NO}_{3}^{-}$clearly cycles dynamically in waters of lower salinity (higher $\mathrm{Si}$ ). The dominant cycling mechanisms appear to differ seasonally, as described below.

Proceeding from high to low Si values in spring, we initially encounter waters with very low $\mathrm{NO}_{2}^{-}+\mathrm{NO}_{3}^{-} / \mathrm{Si}$ compared to that expected from the river-seawater mixing (Figure 8). These samples were from within the turbidity maximum, where photosynthetic uptake cannot be the nitrate sink. Rather, the associated high methane values in some samples (square symbols) strongly suggest that interactions with anoxic bottom and pore water environments were intense. Loss of $\mathrm{NO}_{2}^{-}+\mathrm{NO}_{3}^{-}$by denitrification (and possibly $\mathrm{Si}$ injection by redissolution) are likely the dominant processes redefining the $\mathrm{NO}_{2}^{-}+\mathrm{NO}_{3}^{-} / \mathrm{Si}$ ratios here.

At intermediate [Si] the data fall on the high $\mathrm{NO}_{2}^{-}+$ $\mathrm{NO}_{3}^{-} / \mathrm{Si}$ side of the mixing line and the highest values are associated with unusually high nitrite concentrations (trian- gles), often with $\mathrm{NO}_{2}^{-} \mathrm{NO}_{3}^{-}$approaching unity. This combination suggests that very active nitrification was converting ammonia and possibly DON to $\mathrm{NO}_{2}^{-}+\mathrm{NO}_{3}^{-}$. Lewis and Saunders [1989] report $\approx 2.5 \mu \mathrm{M}$ ammonia and $>11 \mu \mathrm{M}$

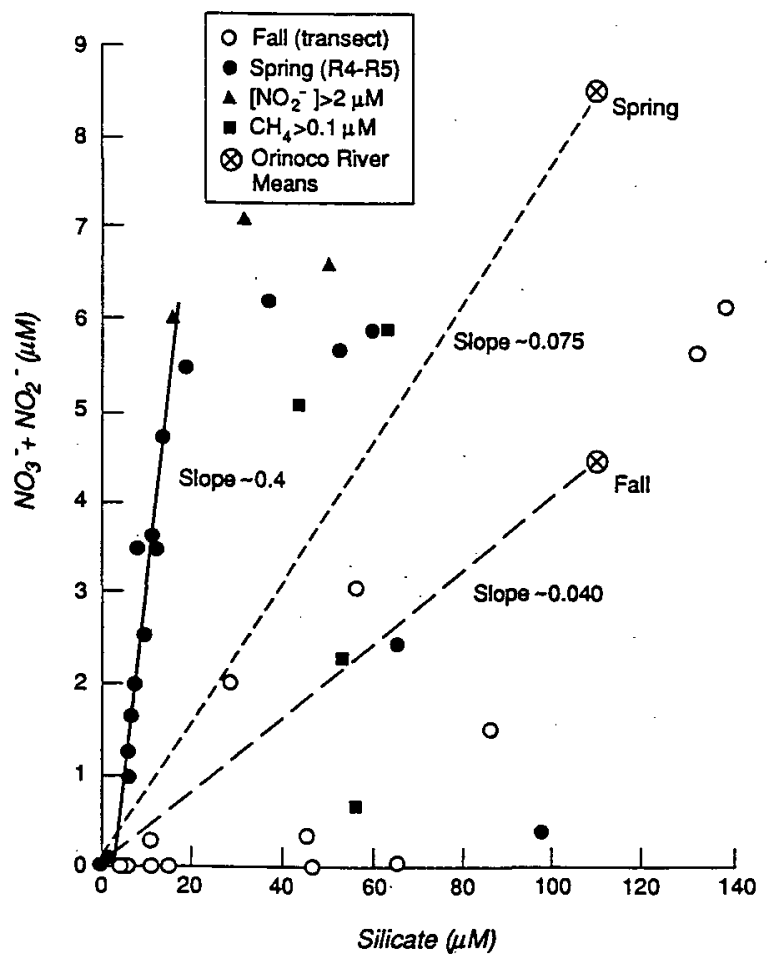

Fig. 8. Plot of nitrite and nitrate versus silicate in surface water for spring and fall 1988. 


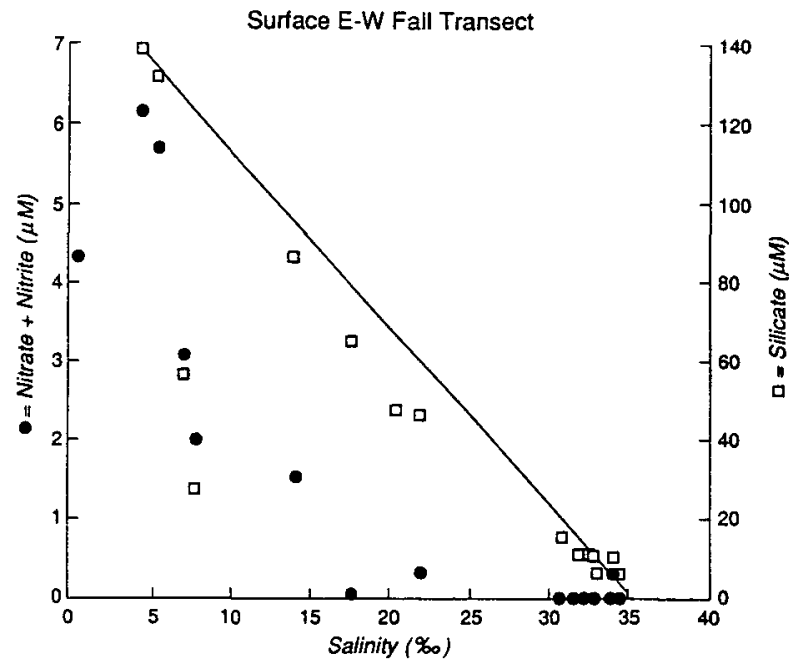

Fig. 9. Plot of nitrite plus nitrate versus salinity and silicate versus salinity from the surface water of E-W transect, fall 1988.

DON in the riverine end-member. Displacement of $\mathrm{NH}_{4}^{+} /$ DON bound to clays by seawater cations in this zone of intense mixing would provide a mechanism to free new substrate for subsequent oxidation to nitrite by bacteria [Carpenter and Capone, 1983], while the high turbidity would minimize light inhibition [Olson, 1981; Vanzella et al., 1989]. Finally, at $<20 \mu \mathrm{M}$ Si this high $\mathrm{NO}_{2}^{-}+\mathrm{NO}_{3}^{-} / \mathrm{Si}$ water appears to mix conservatively with oligotrophic seawater, perhaps with some photosynthetic uptake of $\mathrm{N}$ at the very lowest [Si].

Thus these data show that in spring, nonconservative behaviors indicating biogeochemical cycling and input of $\mathrm{N}$ to coastal waters were intense in this very active zone, generating both relatively $\mathrm{N}$-poor and $\mathrm{N}$-rich waters $(\mathrm{N} / \mathrm{Si}$ ratios $\approx 0.1-5$ of the riverine ratio). However, our sampling was far too sparse and unrepresentative to permit estimating the relative amounts of these two types of water input to the coastal zone over any significant area, and the absence of ammonia and DON data prevents a comprehensive mass balance approach.

In fall (Figure 8, open symbols) the much larger river flow pushed high-Si water out well beyond the core of the turbidity maximum; waters with strongly enriched $\mathrm{NO}_{2}^{-}+$ $\mathrm{NO}_{3}^{-} / \mathrm{Si}$ ratio were absent. The most $\mathrm{Si}$-rich waters were also higher in $\mathrm{NO}_{2}^{-}+\mathrm{NO}_{3}^{-}$than expected from the data of Lewis and Saunders [1989] but in the expected ratio. The fall data are plotted against salinity in Figure 9, revealing estuarine $\mathrm{Si}$ consumption and strong $\mathrm{NO}_{2}^{-}+\mathrm{NO}_{3}^{-}$uptake, especially near $\approx 7 \mathrm{ppt}$ salinity. This presumably reflects photosynthetic uptake by silicoflagellates (see Edmond et al. [1981] concerning this same situation in the Amazon plume). At higher salinities, $\mathrm{Si}$ is more nearly conservative and $\mathrm{N}+$ $\mathrm{N}$ is exhausted. These trends suggest remineralization of $\mathrm{Si}$ and continued uptake of $\mathrm{N}+\mathrm{N}$ by nonsiliceous primary producers at higher salinity. However, in both seasons these interpretations must be tempered by the realization that the system was probably not at steady state, that significant vertical gradients which may have originated by nonconservative processes are ignored, and that the "riverine" (near Barrancas, at the head of the deltaic region) endmember data of Lewis and Saunders [1989] or our samples at
Boca Grande (R4-R5) may not typify the myriad other unsampled distributaries to the NE and entering the Gulf of Paria.

\section{Gulf of Paria and Inputs to the Caribbean}

Although some Orinoco and coastally trapped Amazon water enters the Caribbean by way of Galleons Passage $\mathrm{N}$ of Trinidad, efflux out of the Boca de Dragon is thought to represent a major component of the estuarine input to the Caribbean, as shown strikingly by satellite photographs [Müller-Karger et al., 1990].

The gyre circulation in this Gulf [Bonilla, 1977; D'Armas, 1986] tends to homogenize its waters, including the inputs of the northernmost distributaries discharging into the Gulf itself. Hence it is especially interesting to examine the behavior of $\mathrm{Si}$ on this scale. Taking our riverine end-member values and $\mathrm{R} 1$ as a seaward end-member for Atlantic water entering the Caribbean in the vicinity of the Grenada passage, conservative mixing of surface waters in spring predicts $\approx 18 \mu \mathrm{M}$ silicate at $\mathrm{P} 1 ;<7 \mu \mathrm{M}$ was present. Thus at low discharge, the residence time of water in the Gulf is apparently long enough that substantial biological removal occurs.

In contrast, in fall Si appears to be conservative along the coast and in the Gulf of Paria (Figure 10 inset), despite evidence for localized Si removal (Figure 9). Presumably, either this $\mathrm{Si}$ was regenerated and re-entrained in the flow (perhaps in the course of turbulent mixing in the Boca de Serpente), or the fraction of the total flow thus affected was minor. This mixing line thus defines the Gulf of Paria source water to the Caribbean (at this time) as having an endmember value of $\approx 120 \mu \mathrm{M} \mathrm{Si}$ representing river water (Orinoco plus coastally trapped Amazon flows) little modified by dilution by rainfall or biological removal. This differs from Froehlich et al. [1978] estimate of average freshwater input to the eastern Caribbean (for the entire eastern Caribbean, a significant amount presumably being Amazon water entering with the North Equatorial and Antilles currents through more northern passages) had an apparent endmember composition of $\approx 60 \mu \mathrm{M} \mathrm{Si}$, corresponding mostly to three-component mixing of Amazon water (with nearly the same Si content as Orinoco water, $\approx 130 \mu \mathrm{M}$ ), rainfall, and oligotrophic surface seawater.

Figure 10 is an Si-salt plot with our end-member mixing line (dashed), that of Froehlich et al. [1978] (heavy solid), and the surface $\mathrm{Si}$ data for the entire east. Caribbean cruise track (Figure 1) in fall 1988. Much of the data lie near the line of Froehlich et al. [1978], especially if adjusted to assume an end-member with $0.5 \mu \mathrm{M}$ Si at $36.2 \mathrm{ppt}$ rather than the value of 1 at 36.4 they used (light line). However, to the north (up to about $13^{\circ} \mathrm{N}$ ) many points lie in between these two or along our mixing lines. If $\mathrm{Si}$ is nearly conserved in the $\mathrm{E}$ Caribbean, our Si data suggest a modified view of the threecomponent mixing concept to account for the fact that the Gulf of Paria component is apparently little diluted by rain, whereas the "offshore Amazonian" inputs supply raindiluted riverine $\mathrm{Si}$.

Thus our Si data more or less directly demonstrate the existence in fall of two freshwater/Si inputs and show that the source of high $\mathrm{Si}$ water is at least partly associated with the Orinoco input through the Gulf of Paria, up to $\approx 13^{\circ} \mathrm{N}$. These findings thus reinforce the conclusion from ${ }^{228} \mathrm{Ra}$ data by Moore et al. [1986] that two discrete routes of delivery for 


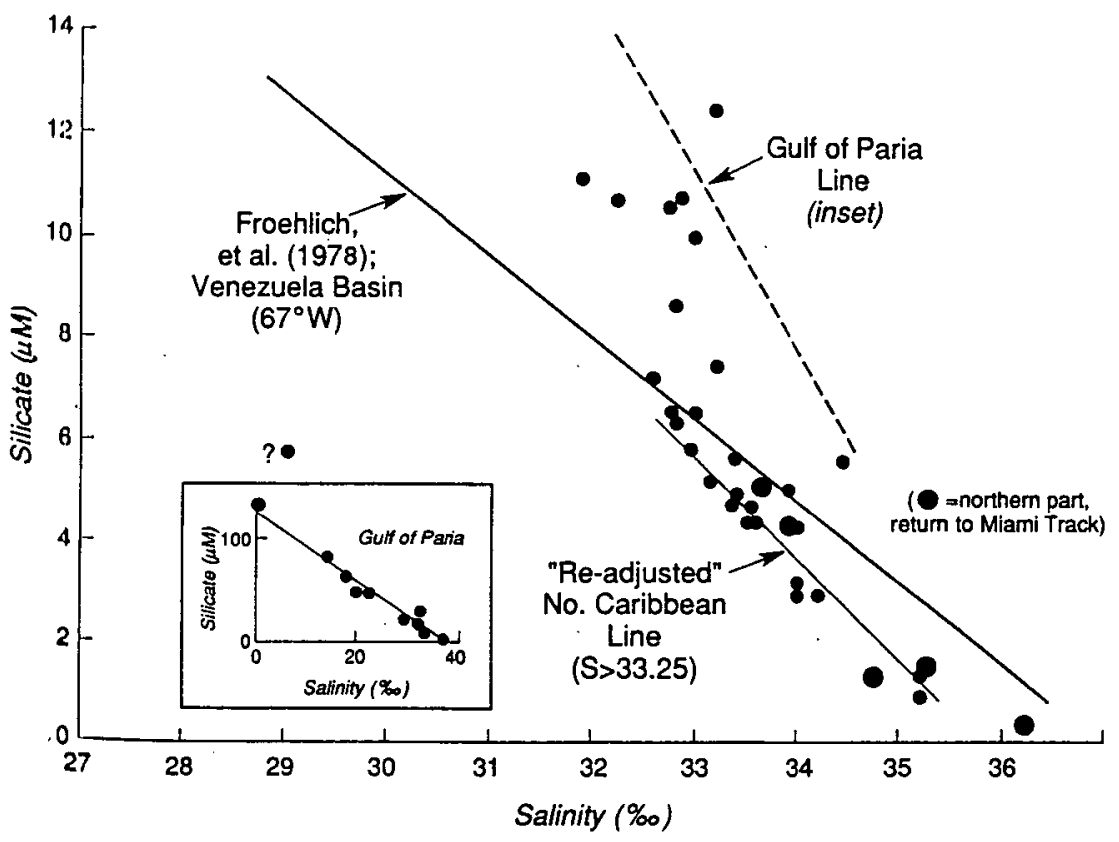

Fig. 10. Plot of silicate versus salinity for the surface waters of the East Carribean cruise track and the Gulf of Paria, fall 1988.

the riverine waters exist [see also Moore and Todd, this
issue].

\section{Spring and Fall Distributions of Primary Productivity}

On a larger scale, Ruther et al. [1967] suggested that diluting $N$ inter actually depressed productivity off Brazil by suggest a mussive fertilization Müller-Karger et al. [1990] Orinoco nutrients fertilization of the eastern Caribbean by ammonia and nitrogemas inputs to do not permit us to evaluate the in fall there is mats to the eastern Caribbean, though clearly waters exit the Gulfive nitrate depletion (Figure 9) before productivity values of Paria. The absence of small primary normally enhunced close inshore in either season shows a light. turhitity, and salinity productivity, despite the fact that data by Bxivere and salinity stresses must be strong. The from piement et al. [this issue] offer confirming evidence give an annroximntes. Thus the primary productivity data takes effect close inte indication that riverine fertilization nutrients close inshore (Figures 6 and 7). If sufficient $N$ fertilize the Curibass through the Gulf of Paria to et al. [1950), thisbean Basin (as assumed by Müller-Karger ical recichins processes must be due to efficient biogeochemductive vrater mass.

Acknowientements. This werk was supported by National Scicontraces Nivilil-14-87-K OCE $\$ 700576$ and OCE 8620249, ONR Captain and 1 -14-87-K-000" and N00014-89-J-1258. We thank the This wort netw of the R/V Criumbus lselin for assistance at sea. National Sit cirtially the rewert of research sponsored by NOAA

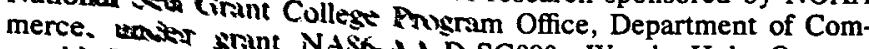
graphic lowarant NASA-A-D-SG090, Woods Hole Oceanoment is

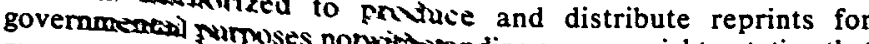
may appear herroun.

\section{REFERENCES}

Benitez-Alvarez, J., and T. Okuda, Distribución de nitrógeno orgánico particulado en el Golfo de Paria, Bol. Inst. Oceanogr. Univ. Oriente, 15, 3-14, 1976.

Bidigare, R. R., M. E. Ondrusek, and J. M. Brooks, Influence of the Orinoco River outflow on distributions of algal pigments in the Caribbean Sea, J. Geophys. Res., this issue.

Bonilla, R. J., Condiciones hidroquimicas del agua y caracteristicas quinicas de los sedimentos del Golfo de Paria durante la expedicion oceanografica LS-7302, Bol. Inst. Oceanogr. Univ. Oriente, 16, 99-14, 1977.

Bonilla, R. J., and A. L. Lin, Materia orgánica en los sedimentos de los Golfos de Paria y Cariaco, Venezuela, Bol. Inst. Oceanogr. Univ. Oriente, 18, 37-52, 1979.

Bonilla, R. J., Y. Poyer, and B. Gambra, Características geoquímicas en núcleos de sedimentos de la región Nororiental y río Orinoco, Venezuela, Bol. Inst: Oceanogr. Univ. Oriente, 24, 43-61, 1985

Burton, J. D., P. S. Liss, and V: K. Venrigopalan, The behavior of dissolved silicon during estuarine mixing, I, Investigation in Southampton water, J. Cons. Perm. Int. Explor. Mer, 33, 134 $140,1970$.

Butenko, J., J. P. Barbot, and J. Daza, Singularidades geologicas exploradas con el minisubmarino del Calypso en Venezuela, $R e v$. Tec. Intevep., 1, 27-35, 1981.

Carpenter, E. J., and D. G. Capone (Eds.), Nitrogen in the Marine Environment, Academic, San Diego, Calif., 1983.

D'Armas, H., Características hidroquímicas del Golfo de Paria como un sistema estuarino, M.S. thesis, 158 pp., Inst. Oceanogr. de Venezuela, Univ. de Oriente, Cumaná, 1986.

Edmond, J. M., E. A. Boyle, B. Grant, and R. F. Stallard, The chemical mass balance in the Amazon plume, I, The nutrients, Deep Sea Res., 28A, 1339-1374, 1981.

Eisma, D., J. V. Der Gaast, J. M. Martin, and A. J. Thomas, Suspended matter and bottom deposits of the Orinoco Delta: Turbidity, mineralogy and elementary composition, Neth. J. Sea Res., 12, 224-251, 1978.

Froehlich, P. N., Jr., D. K. Atwood, and G. S. Giese, Influence of Amazon River discharge on surface salinity and dissolved silicate concentration in the Caribbean Sea, Deep Sea Res., 25, 735-744, 1978.

Herrera, L. E., and P. Masciangioli, Caracteristicas de las corrientes frente al Delta del Orinoco, sector Occidental del Océano Atlántico, Rev. Tec. Intevep., 4, 133-134, 1984. 
Kennicutt, M. C., II, C. Barker, J. M. Brooks, D. A. DeFreitas, and G. H. Zhu, Selected organic matter source indicators in the Orinoco, Nile and Changiiang deltas, Org. Geochem., 14, 41-51, 1987.

Lewis, W. M., and J. F. Saunders, Concentration and transport of dissolved and suspended substances in the Orinoco River, Biogeochemistry, 7, 203-240, 1989.

Liss, P. S., Conservative and non-conservative behaviour of dissolved constituents during estuarine mixing, in Estuarine Chemistry, edited by J. D. Burton and P. S. Liss, vol. 4, pp. 93-130, Academic, San Diego, Calif., 1976.

MacDonald, R. W., E. C. Carmack, F. A. McLaughlin, K. Iseki, D. M. MacDonald, and M. C. O'Brien, Composition and modification of water masses in the Mackenzie Shelf Estuary, J. Geophys. Res., 94(C12), 18,057-18,070, 1989.

Milliman, J. D., J. Butenko, J. P. Barbot, and J. Hedberg, Depositional patterns of modern Orinoco/Amazon muds on the northern Venezuelan sheif, J. Mar. Res., 40, 643-657, 1982.

Moore, W. S., and J. F. Todd, Radium isotopes in the Orinoco Estuary and eastern Caribbean Sea, J. Geophys. Res., this issue.

Moore, W. S., J. L. Sarmiento, and R. M. Key, Tracing the Amazon component of surface Atlantic water using ${ }^{228} \mathrm{Ra}$, salinity, and silica, J. Geophys. Res., 91, 2574-2580, 1986.

Morelock, J., Guyana-Orinoco continental shelf sediments, Bol. Inst. Oceanogr. Univ. Oriente, 11, 57-61, 1972.

Müller-Karger, F. E., and R. J. Varela, Variabilidad de la biomasa de fitoplancton en aguas superficiales del Mar Caribe con el CZCS, EDIMAR FLASA Contrib., 171, 1-23, 1988.

Müller-Karger, F. E., C. R. McClain, T. R. Fisher, W. E. Esaias, and R. Varela, Pigment distribution in the Caribbean Sea: Observations from space, Prog. Oceanogr., 23, 23-64, 1990.

Olson, R. J., Differential photoinhibition of marine nitrifying bacte- ria: A possible mechanism for the formation of the primary nitrite maximum, J. Mar. Res., 39, 227-238, 1981.

Rodriguez, G., Some aspects of the ecology of tropical estuaries, in Tropical Ecological Systems: Trends in Terrestrial and Aquatic Research, Ecol. Stud. Ser. II, edited by F. B. Golley and E. Medina, pp. 313-333, Springer-Verlag, New York, 1975.

Ryther, J. H., D. W. Menzel, and N. Corwin, Influence of the Amazon River outflow on the ecology of the western tropical Atlantic, I, Hydrography and nutrient chemistry, J. Mar. Res., $25,69-83,1967$.

Salazar, J. C., Condiciones hidrogeoquínicas de la región estuarinadeltaica del Orinoco durante el mes de noviembre de 1985, M.S. thesis, 128 pp., Inst. Oceanogr. Venezuela, Univ. de Oriente, Cumaná, 1989.

Vanzella, A., M. A. Guerrero, and R. D. Jones, Effect of CO and light on ammonium and nitrite oxidation by chemolithotrophic bacteria, Mar. Ecol. Prog. Ser., 57, 69-76, 1989.

Zika, R. G., P. J. Milne, and O. G. Zafiriou, Photochemical studies of the eastern Caribbean: An introductory overview, J. Geophys. Res., this issue.

J. Bonilla and W. Senior, Instituto Oceanográfico de Venezuela, Universidad de Oriente, Cumaná, Venezuela.

J. Bugden and R. Jones, Department of Biological Sciences and Drinking Water Research Center, Florida International University, Miami, FL 33199.

O. Zafiriou, Woods Hole Oceanographic Institution, Woods Hole, MA 02543.
(Received May 10, 1991;

revised February 14, 1992;

accepted February 21, 1992.) 